\title{
Analysis of Landing Error Scoring System for Evaluating the Anterior Cruciate Ligament Risk Factors of Muscle Mass in Female
}

\author{
Jung-Wha Moon', Ji-Hoon Cho², Seung-Taek Lim ${ }^{3,4^{*}}$, Bee-Oh Lim* \\ ${ }^{1}$ Sports Medical Center Ilsan Paik Hospital Inje University, Goyang-si, Gyeonggi-do, Korea \\ ${ }^{2}$ Shingyeong University Department of Sports \& Leisure Studies, Hwaseong-si, Gyeonggi-do, Korea \\ ${ }^{3}$ Institute of Sport Science, Kangwon National University, Kangwondaehak-gil, Chuncheon-si, Gangwon- do, Korea \\ ${ }^{4}$ Nasaret International Hospital, Incheon, Korea \\ ${ }^{5}$ Department of Physical Education, Chung-Ang University, Seoul, Korea
}

Received: June 21, 2018

Accepted: July 30, 2019

Published online: July 31, 2019

Keywords:

Landing Error Scoring System

Muscle Mass

Percent Fat

Percent Muscle

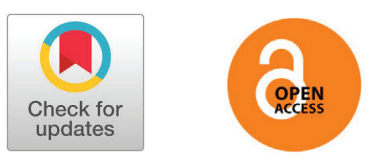

\section{ABSTRACT}

OBJECTIVES The purpose of this study is to analyze the landing error scoring system for the evaluation of the risk factors of anterior cruciate ligament of female according to muscle mass and to identify the risk factors of anterior cruciate ligament according to percent muscle

METHODS In order to evaluate the risk factors of anterior cruciate ligament for 20 women in their 20s low muscle group and high muscle group, they were analyzed to landing error scoring system jump from a $30 \mathrm{~cm}$-high box to a $50 \%$ distance of height, from a $45 \mathrm{~cm}$-high box to a distance of $50 \%$ and $75 \%$ distance of height.

RESULTS Body composition showed that percent fat of the low muscle group was $32.4 \pm 2.7 \%$, and percent muscle was $63.3 \pm 2.7 \%$. Percent fat of the high muscle group was $26.8 \pm 3.0 \%$, and percent muscle was $68.5 \pm 2.9 \%$ and there was a significantly difference between the two groups $(p<.001)$. The landing error scoring system is 50 percent to 6.6 points for the low muscle group, 4.3 points for the high muscle group at the height of $30 \mathrm{~cm}(p<.01), 7.1$ points for the low muscle group at the height of $45 \mathrm{~cm}, 5.5$ points for the high muscle group ( $p<.05)$, and 75 percent to 8.3 points for the low muscle group and 6.8 points for the high muscle group at the height of $45 \mathrm{~cm}(p<.05)$. There were statistically significant differences between the two groups.

CONCLUSIONS Muscle mass and percent muscle are closely related to anterior cruciate ligament damage. That is to say, the risk of damage to the anterior cruciate belt due to landing tax errors was low muscle group higher than that of high muscle group. Therefore, it is suggested that exercise items that improve muscle mass will be necessary to create a forward anterior cruciate ligament damage prevention program.

() The Asian Society of Kinesiology and the Korean Academy of Kinesiology
서론

무릎관절 손상 발생 비율이 가장 높은 부위는 전방

*Correspondence: Seung-Taek Lim, Institute of Sport Science, Kangwon National University, Kangwondaehak-gil, Chuncheon-si, Gangwon- do, 24341, Republic of Korea Nasaret International Hospital 98, Meonugeum-ro, yeonsu-gu, Incheon, 21972, Republic of Korea; Tel: +82-10-3741-3205; E-mail: limdotor@gmail.com **Correspondence: Bee Oh Lim, Department of Physical Education, Chung-Ang University, 84 Heukseok-ro, Dongjak-gu, Seoul 06974, Korea; Tel: +82-2-820-5121, Fax: +82-2-812-2729; E-mail: bolim@cau.ac.kr
십자인대이다 [1, 2] . 전방십자인대 손상의 $70 \%$ 이상 이 방향전환이나 점프 후 착지할 때 발생되는 비접촉성 부상인 것을 보면 점프 후 착지 과정에서 체중이 부하 로 작용하는 전방십자인대 위험요인의 평가 연구는 매 우 중요하다 [3-5].

전방십자인대 손상은 남성보다 여성이 발생 빈도가

This is an open-access article distributed under the terms of the Creative Commons Attribution License (http://creativecommons.org/licenses/by-nc/4.0/), which permits unrestricted use, distribution, and reproduction in any medium, provided the original work is properly cited. 
높은데 [6] , 특히 전방십자인대 파열은 남성에 비해 여성이 2-10배 높게 발생하는 것으로 보고되고 있다 [7-9]. 전방십자인대 손상이 남성보다 여성에서 발 생 빈도가 높은 주된 원인 중의 하나는 성별에 따른 근 육량의 차이이다 [10-12] . 성장하는 동안 여성은 남 성에 비해 대퇴 근력이 덜 발달하고, 넙다리네갈래근 (quadriceps)에 비해 뒤넙다리근(hamstrings)의 근력 이 덜 발달해서 전방십자인대 부상 위험이 더 증가하게 된다 [13] . 그러나 같은 여성 중에서도 체내 많은 근 육량은 근력과 비례하며, 하지 근육은 무릎을 안정화시 키는데 많은 영향을 미친다고 하였다 [14] . 여성이 전 방십자인대 손상에 노출되기 쉬운 연령은 학령기인 8 세에서 24세로 스포츠 참여가 활발한 시기이며 부상이 가장 많은 시기이다 $[15,16]$. 따라서 이 시기에 여 성의 전방십자인대 손상 위험인자 평가는 필수적이다.

전방십자인대 손상 위험 인자를 평가하는 검사방법 으로 가장 대표적인 검사방법은 3 차원 동작분석시스템 검사이다 [17]. 그러나 동작분석시스템은 고가의 장 비로 많은 시간이 요구되고 분석 절차가 복잡하여 스 포츠 현장이나 일반 대중에게 바로 적용시키기에는 큰 한계가 있다. 그 대안으로 가장 많이 이용되는 방법은 착지오류점수시스템(landing Error Scoring System; LESS)이다 [15, 18] . Padua et al. [18] , 은 착지오 류점수시스템(LESS)은 전방십자인대 손상 평가도구로 비 접촉성 전방십자인대 손상 위험에 노출된 대상자를 식별하기 위해 개발되었으며, 타당도와 신뢰도가 높은 임상 평가도구라고 보고하였다. 착지오류점수시스템은 좁은 장소에서 단시간에 많은 사람들에게 적용시킬 수 있고 스포츠 현장이나 학교체육시설에서 다수의 모집단 에게 적용하기 쉽다 $[9,19,20]$. 착지오류점수시스템 (LESS)은 무릎 손상의 위험을 줄이고 무릎 손상을 예 방하는데 중요한 지표로 이용될 수 있다. 여성 간의 전 방십자인대 손상 위험에 대한 차이 비교연구는 연령에 따른 연구가 몇몇 보고되었으며, 다른 여러 위험 요인 에 대한 연구는 미비하다. 선행연구에서는 사춘기 전, 중, 후 여성들을 대상으로 하지의 부상위험에 대한 연구 [19-21] 와 여성 대학생의 전방십자인대 부상 위험요 인에 대한 연구 $[8,19]$ 등이 있었으며, 양 발 착지 시 [19-21] 와 한 발 착지 시 전방십자인대 손상에 대한 연구 등이 보고되었다 [5, 19-25]. 그러나 여성의 근 육량(muscle mass)과 체중 대비 균육량 비율을 뜻하는 근육률(percent muscle)에 따른 무릎 손상 위험에 대한 비교 연구는 미비한 실정이다. 시대의 변화로 여성의 스 포츠 활동이 증가되면서 $[5,6,11,12,14,26,27]$, 학교 체육시설이나 $[6-8,25]$ 스포츠 현장에서 [8, 9, 11, 12] Padua et al. [18], 의 착지오류점수시스 템 평가 방법 보다 더 큰 위험에 빈번히 노출될 수 있다. 예들 들어, 학교 체육시설에서는 높은 철봉이나 구름사 다리, 미끄럼틀, 그네 등에서 점프하는 경우 농구, 배구, 핸드볼, 축구, 도움닫기 멀리뛰기나 제자리 멀리뛰기, 뜀 틀운동 중 두 발로 착지하는 경우 [5, 6, 9, 23-25] , 놀이시설이나 사설 체육시설에서는 트램폴린에서 점프, 발레, 마샬아츠 트릭킹(martial arts tricking), 에어로빅 댄스에서 두발 점프 후 착지 동작, 비보잉, 방송댄스, 암 벽 클라이밍, 크로스핏 운동 중 박스점핑 등 [24, 28] 다양한 운동 현장에서 $30 \mathrm{~cm}$ 이상의 높이와 자신의 신 장의 $50 \%$ 거리 이상 떨어진 지점에서 착지하는 위험에 노출될 수 있다 [29]. 그러나 여성의 스포츠활동 증가 에 따른 전방십자인대 위험요인의 증가를 반영한 착지 오류점수시스템(LESS) 평가를 다양한 방법으로 접근하 여 적용(Modify)한 선행연구는 미비한 실정이다. 따라서 Padua et al. [15, 18] 의 착지오류점수시스템 평가를 근거로 여성의 스포츠활동의 증가에 따른 전방십자인대 위험 요인 평가의 다양한 연구를 위해 $45 \mathrm{~cm}$ 높이에서 자신의 신장의 $50 \%$ 거리로 착지 후 수직점프, $45 \mathrm{~cm}$ 높 이에서 자신의 신장의 $75 \%$ 거리로 착지 후 수직점프 방 법을 Padua et al. [18] 의 착지오류점수시스템(LESS) 평가 방법과 비교 연구할 필요가 있다.

성인 여성의 체질량지수(Body Mass Index; BMI) 와 허리둘레(Waist Circumference; WC)가 비만 진 단 기준 미만이면 체지방량(fat mass; FM)과 체지방률 (percent fat; \%fat), 근육량(muscle mass; MM)과 근 육률(percent muscle; \%muscle)에 상관없이 정상으로 진단한다 [28] . 그러나 정상 체질량지수와 허리둘레 를 가지고 있는 성인 여성 중에서도 근육량이 적고 체 지방량이 많은, 즉 체지방률이 높고 체중 대비 근육률 (\%muscle)이 낮은 날씬한 비만인 경우가 많다. 이러한 단점을 보완하기 위해 이미 임상과 전국 보건소, 스포츠 현장에서는 체지방량과 체지방률, 근육량과 근육률을 확 인하기 위해, 즉 진짜 건강한지를 확인하기 위해 체성분 검사가 보편적으로 광범위하게 이용되고 있다 [29] . 체성분검사는 생체전기저항법(Bioelectric Impedance 
Analysis; BIA)으로 체수분을 이용하여 체내의 근육량 과 지방량의 비율과 분포를 확인할 수 있는 간접측정법 이다. 체성분검사는 비만도를 평가하는 간접측정법 중 에서 신뢰도가 가장 높은 피부두겹법(skinfold)과 비교 하여 [30] 신뢰도가 높은(r=.70 .90) 검사방법이다. 체성분검사에서 체지방률이 남성은 $25 \%$ 이상, 여성은 $30 \%$ 이상을 비만으로 평가한다 [29] .

비만 여성과 정상 여성의 전방십자인대 손상 위험은 은 당연 비만 여성이 높을 것으로 예측될 수 있다. 그러 나 체질량지수(BMI)와 허리둘레(WC)가 정상인 여성 중에서 체내 근육량의 많고 적음을 나타내는 근육률에 따른 전방십자인대 손상 위험도에 대한 연구는 더욱 미 비한 실정이다.

따라서 이 연구에서는 20 대 건강한 성인 여성들을 대상으로 근육량과 근육률에 무릎 관절의 전방십자인대 손상 위험 평가지표인 드롭 수직점프 시 착지오류점수 시스템 차이를 규명하고자 한다.

\section{연구방법}

\section{1. 연구대상}

본 연구는 서울시에 거주하는 최근 3 개월 이상 규 칙적인 운동을 하고 있지 않은 건강한 20 대의 성인 여 성 20명을 대상으로 하였다. 연구 대상자의 표본크기는 G*power 3.1.2 프로그램을 이용하여 중간수준의 효 과크기 .80 , 유의수준 .05 그리고 검정력 .95 결과 본 연구에 필요한 총 대상자 수는 20명으로 나타났다. 연 구 대상 선정은 사전 설문조사를 통해 병력과 최근 3 개 월 동안의 규칙적인 운동이나 신체활동 여부, 정형외과 적 질환 등을 고려한 선정기준 및 제외기준에 적합한 대 상자를 정하였다. 연구대상 선정기준은 1) 체질량지수 $25 \mathrm{~kg} / \mathrm{m}^{2}$ 미만인 자, 2) 허리둘레 $85 \mathrm{~cm}$ 미만인 자이다 [28] . 연구대상 제외기준은 1) 체질량지수 $25 \mathrm{~kg} / \mathrm{m}^{2}$ 이상인 자, 2) 허리둘레 $85 \mathrm{~cm}$ 이상인 자, 3) 정형외과 적 질환을 진단받았거나 수술한 경험이 있는 자, 4) 운 동을 하면 심해지는 중증 정형외과적 질환 및 중증 류 마티스성 질환으로 점프운동이 불가능한 자, 5) 최근 3 개월 동안 어지럼증으로 쓰러지거나 실신한 적이 있는 자, 6) 최근 3 개월 동안 주 3 회 이상 규칙적으로 운동 및 신체활동을 한 자, 7) 연구기간 동안 임신을 하게 되 거나, 현재 임신중인 자, 8) 현재 다른 임상시험에 참여
중인 자, 9) 중대한 신경정신과 질환으로 약물복용 중 이거나 치료중인 자, 10) 기타 연구에 참여가 부적합하 다고 판단되는 자이다.

\section{2. 연구절차}

모든 검사는 사전에 연구의 목적과 내용, 실험 방법 에 대해 충분한 설명과 피험자의 자발적 사전 동의 하 에 검사를 시행하였고, 연구윤리위원회의 허가를 얻었 다(1041078-201802-HRBR-039-01).

\section{1) 체질량지수}

신장, 체중은 신장체중측정기(Fanics, KOREA)에 올 라서서 허리를 펴고 시선은 전방을 향하게 하고 눈과 귀 의 높이가 수평이 되게 하여 측정하였다. 측정된 신장, 체중으로 계산하여 체질량지수 값을 얻었다.

\section{2) 체성분}

체성분검사는 검사 상의 신뢰도를 높이기 위해 검사 48시간 전부터 금주하고 검사 전날 저녁식사 후부터 8 시간 이상 금식하여 검사 당일 오전에 공복으로 실시하 였는데 검사 30 분 전에 배뇨하도록 하였다. 또한 과량의 카페인이나 음료를 섭취하지 않도록 하였으며, 검사 전 12 시간 동안 장시간의 지나친 운동이나 탈수 가능성이 있는 사우나는 삼가도록 하였다. 또한 검사 전 7일 동안 이뇨제 복용을 금했다. 검사 복장은 준비된 반팔 상하의 운동복으로 통일하였고 목걸이, 시계, 반지 등의 소지품 을 제거한 후 검사를 실시하였다 [28] .

체성분검사는 생체전기저항 분석 장비(Inbody 16.0, Biospace, KOREA)를 이용하여 체중(weight), 체지방 량(fat mass), 체지방률(percent fat), 제지방량(fat free mass), 근육량(muscle mass)을 측정하였다. 측정된 체 중과 근육량 값을 이용해 근육량이 체중의 몇 퍼센트를 차지하는지를 계산하여 근육률(\% muscle)을 환산하였 다. 20 명의 연구 참가자는 체성분검사 결과를 이용하 여 체지방률 $30 \%$ 이상이고 근육률이 낮은 저근육 집 단(Low Muscle Group; LMG)과 체지방률 30\% 미만 이고 근육률이 높은 고근육 집단(High Muscle Group; $\mathrm{HMG}$ )으로 각각 10 명씩 분류하였다.

\section{3) 착지오류점수시스템}

착지오류점수시스템(LESS)은 비접촉성 전방십자인 대 위험요인 평가 방법으로, 본 연구에서는 관상면과 시 
상면에서 비디오 분석을 통하여, 드롭 수직점프 후 착 지 시 지면과의 초기 접촉할 때 몸통의 위치, 최대 굴곡, 관절의 유동성과 관절운동범위를 평가하는 Padua, et al [18] 에 의해 시행된 방법을 사용하였다. 착지오류 점수시스템은 실험실에 정면과 측면을 기록하는 두 대의 측정용 카메라(VM-HMX20C, INDONESIA)와 $30 \mathrm{~cm}$, $45 \mathrm{~cm}$ 높이의 도약대로 이루어져 있다. 착지 위치에서 $3.5 \mathrm{~m}$ 의 거리를 두고 대상자의 오른쪽 무릎관절 방향의 측면과 정면 $1.2 \mathrm{~m}$ 의 높이에 비디오카메라를 각각 설 치하였다 [23] . 착지오류점수시스템 검사는 $30 \mathrm{~cm}$ 와 $45 \mathrm{~cm}$ 높이의 도약대 위에 서서 양 발로 착지 후 드롭 수직점프 동작을 하는 방법으로 1) $30 \mathrm{~cm}$ 높이의 박스 위에서 자신의 신장의 $50 \%$ 거리 떨어진 지점에 양 발 착지 후 수직으로 점프하는 동작, 2) $45 \mathrm{~cm}$ 높이의 박스 위에서 자신의 신장의 $50 \%$ 거리 떨어진 지점에 양 발 착지 후 수직으로 점프하는 동작, 3) $45 \mathrm{~cm}$ 높이의 박 스 위에서 자신의 신장의 $75 \%$ 거리 떨어진 지점에 양 발 착지 후 수직으로 점프하는 동작을 3 회 연습하고 5 분 간 휴식을 취한 후 3 회씩 수행하도록 하였다. 이때 착지 후 즉각적으로 도약하는 순간에 발생하는 자세의 오류를 항목별로 점수화하는 착지오류점수시스템을 평 가하였다 [Figure 1]. 두 대의 비디오카메라에 기록 된 영상 중 발이 바닥에 닿기 시작하는 착지 초기와 다 시 공중으로 뛰어오르기 전 무릎관절의 최대 굴곡 시점 에서 잘못된 착지 동작인 오류를 찾아내어 점수를 기록 하였다. 측면 영상에서는 총 8 가지 항목에서 최고 9 점 의 오류 점수가 확인되었으며, 정면의 영상에서는 총 8 가지 항목에서 최고 8점의 오류점수가 확인되었다. 마 지막으로 정면과 측면의 영상을 종합적으로 판단하여 0 2점을 부가하였으며 최고 점수는 19점이었다. 착지 오류점수는 우수한 착지(excellent: 4점 이하), 좋은 착 지(good: 4 5점), 보통 착지(moderate: 5 6점), 잘못 된 착지(poor: 6점 이상)로 분류되어 있다 [18] . 비 디오카메라에 기록 된 착지오류점수시스템 분석을 위 한 무릎관절의 최대 굴곡 시점인 각도의 계산은 동영상 분석 프로그램인 [31] 키노베아(Kinovea ver. 0.8.15 software (Kinovea; boston, MA, USA))를 사용하였 다 [Figure 2].

\section{3. 자료처리}

이 연구에서 측정된 모든 결과 값의 통계분석은 $\mathrm{BMSPSS}$

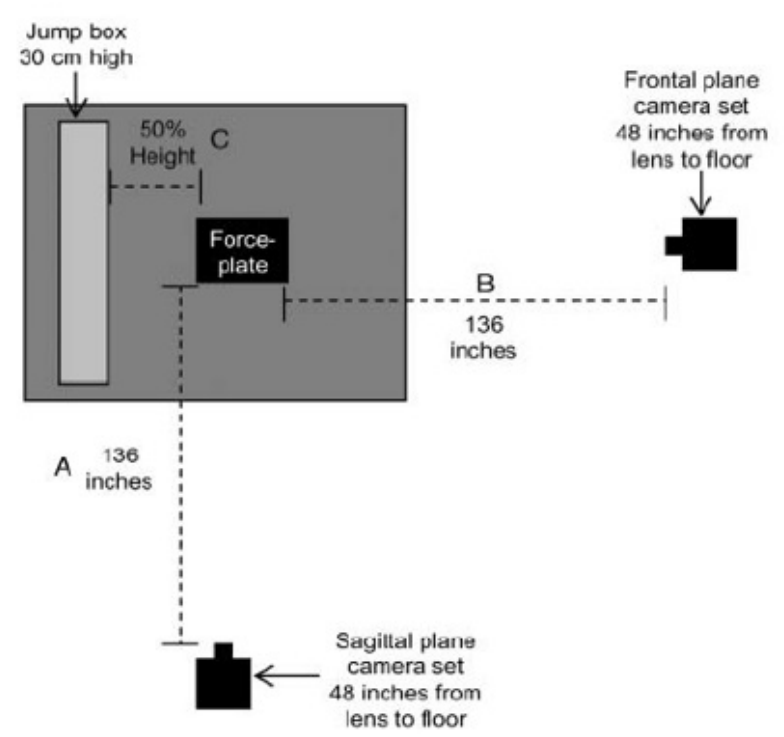

Figure 1. Composition of landing error scoring system (Cho \& Lim (2017))
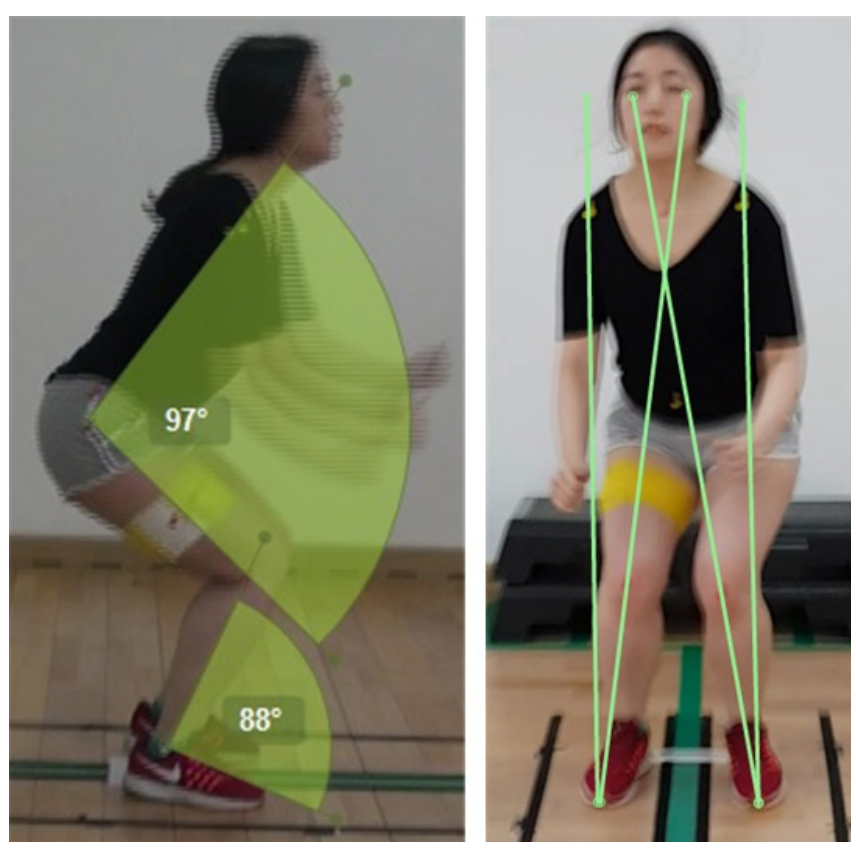

Figure 2. Video Analysis Program

ver. 21.0 (BBM Corp., Armonk, NY, USA)을 이용하여 모든 변 인의 평균과 표준편차를 산출하였다. 저근육 집단과 고근육 집단 간의 차이 분석을 위하여 독립표본 t-test를 적용하였다. 모 든 결과의 통계적 유의수준은 $\mathrm{a}=.05$ 로 정하였다.

\section{결과}

\section{1. 체질량지수 및 체성분}

저근육 집단( $\mathrm{LMG})$ 과 고근육 집단( $\mathrm{HMG})$ 의 체질량 
지수와 체성분 결과는 Table 1 과 같다.

\begin{tabular}{|c|c|c|c|}
\hline \multirow[b]{2}{*}{ Variable } & \multicolumn{2}{|c|}{ Group } & \multirow[b]{2}{*}{ p-value } \\
\hline & $\begin{array}{l}\text { Low Muscle } \\
\text { Group }(n=10)\end{array}$ & $\begin{array}{l}\text { High Muscle } \\
\text { Group }(n=10)\end{array}$ & \\
\hline Age(yrs) & $23.90 \pm 5.21$ & $22.70 \pm 3.16$ & .542 \\
\hline Height(cm) & $164.38 \pm 4.86$ & $163.44 \pm 3.48$ & .625 \\
\hline Weight(kg) & $59.90 \pm 7.02$ & $55.96 \pm 4.21$ & .145 \\
\hline Body Mass Index $\left(\mathrm{kg} / \mathrm{m}^{2}\right)$ & $22.10 \pm 1.75$ & $20.94 \pm 1.40$ & .120 \\
\hline Fat Mass(kg) & $19.46 \pm 2.76$ & $15.06 \pm 2.37^{* *}$ & .001 \\
\hline$\%$ fat(\%) & $32.46 \pm 2.71$ & $26.86 \pm 3.00^{* * *}$ & .000 \\
\hline Fat Free Mass(kg) & $40.44 \pm 5.01$ & $40.90 \pm 2.88$ & .845 \\
\hline Muscle Mass(kg) & $38.43 \pm 2.75$ & $37.99 \pm 4.76$ & .803 \\
\hline$\%$ Muscle(\%) & $63.34 \pm 2.73$ & $68.51 \pm 2.98^{* * *}$ & .001 \\
\hline
\end{tabular}

두 집단 피험자의 평균 연령, 신장, 체중, 체질량지수 는 통계적으로 유의한 차이가 없었다. 체성분 검사 결과 저근육 집단(LMG)과 고근육 집단(HMG)의 체지방량과 체지방률은 두 집단 간에 통계적으로 유의한 차이가 있 었다 $(\mathrm{p}<.01, \mathrm{p}<.001)$. 저근육 집단( $\mathrm{LMG})$ 과 고근육 집 단(HMG)의 제지방량과 근육량은 두 집단 간에 유의한 차이가 없었으나, 근육률은 두 집단 간에 통계적으로 유 의한 차이가 있었다 $(\mathrm{p}<.001)$.

\section{2. 착지오류점수시스템}

저근육 집단(LMG)과 고근육 집단(HMG)의 착지오 류점수시스템(LESS)은 Table 2 와 같다.

\begin{tabular}{|c|c|c|c|c|}
\hline & \multirow[b]{2}{*}{ Parameters } & \multicolumn{2}{|c|}{ Group } & \multirow[b]{2}{*}{ p-value } \\
\hline & & $\begin{array}{l}\text { Low Muscle } \\
\text { Group }(n=10)\end{array}$ & $\begin{array}{l}\text { High Muscle } \\
\text { Group }(n=10)\end{array}$ & \\
\hline \multirow{3}{*}{ LESS } & $\begin{array}{l}30 \mathrm{~cm} / \text { distance } \\
50 \% / \text { height }\end{array}$ & $6.60 \pm 1.89$ & $4.30 \pm 1.33^{* *}$ & .006 \\
\hline & $\begin{array}{l}45 \mathrm{~cm} / \text { distance } \\
50 \% / \text { height }\end{array}$ & $7.10 \pm 2.02$ & $5.50 \pm 1.08^{*}$ & .045 \\
\hline & $\begin{array}{l}45 \mathrm{~cm} / \text { distance } \\
75 \% / \text { height }\end{array}$ & $8.30 \pm 1.49$ & $6.80 \pm 1.39^{*}$ & .032 \\
\hline $\begin{array}{l}\text { a) LE } \\
{ }^{*} p<\end{array}$ & $\begin{array}{l}\text { anding Error } S \\
*{ }_{* *} p .01{ }^{* * *} p<\end{array}$ & oring System & & \\
\hline
\end{tabular}

1) $30 \mathrm{~cm}$ 높이와 신장의 $50 \%$ 거리 착지오류점수시 스템은 두 집단 간에 통계적으로 유의한 차이가 있었다 $(\mathrm{p}<.01)$.

2) $45 \mathrm{~cm}$ 높이와 신장의 $50 \%$ 거리 착지오류점수시 스템은 두 집단 간에 통계적으로 유의한 차이가 있었다 $(\mathrm{p}<.05)$.

3) $45 \mathrm{~cm}$ 높이와 신장의 $75 \%$ 거리 착지오류점수시 스템은 두 집단 간에 통계적으로 유의한 차이가 있었다 $(\mathrm{p}<.05)$.

\section{논의}

이 연구는 20 대 건강한 성인 여성들을 대상으로 근 육량과 근육률에 따른 무릎 관절의 전방십자인대 손상 위험 평가지표인 드롭 수직점프 시 착지오류점수시스 템의 차이를 규명하는 것이다. 연구 결과, $30 \mathrm{~cm}$ 높이의 박스 위에서 자신의 신장의 $50 \%$ 거리 떨어진 지점에 양 발 착지 후 수직으로 점프하는 동작뿐만 아니라 $45 \mathrm{~cm}$ 높이와 신장의 $50 \%$ 거리, $45 \mathrm{~cm}$ 높이와 신장의 $75 \%$ 거 리 동작에서 저근육 집단이 고근육 집단의 착지오류점 수시스템 보다 더 높게 나타났다. 이는 저근육 집단이 고근육 집단보다 착지자세의 오류로 인한 전방십자인대 의 손상 위험이 더 크다는 것을 의미한다. 착지오류점수 시스템(LESS)의 높은 점수는 잘못된 착지 기술을 나타 내고, 반면에 낮은 점수는 좋은 착지 기술을 나타낸다 [15, 18] . Cho \& Lim [28] 은 착지오류점수시스템 이 6점 이상인 전방십자인대 손상 위험이 높은 연구대상 자와 4점 이하인 전방십자인대 손상 위험이 낮은 연구 대상자 간의 생체 역학적 변인과 수직 지면반력 변인에 서 유의한 차이가 나타났다고 보고하였다. 이 연구에서 는 20 대 건강한 성인 여성들을 대상으로 착지오류점수 시스템의 종합점수 결과를 살펴보면 근육률이 높은 고 근육 집단은 5.5점(보통: 5 6점)으로 보통의 착지수준 을 가지고 있었고, 근육률이 낮은 저근육 집단은 7.3 점( 잘못된 착지: 6점 이상)으로 전방십자인대 손상 위험이 높은 것으로 나타났다. 이와 관련된 선행연구를 살펴보 면, Cho et al. [24], 은 20대 엘리트 여자 축구선수 집 단의 경우 6.88점, 20 대 여자 발레무용수 집단의 경우 5.33점으로 보통 착지 동작을 가지고 있는 것으로 보고 하였다. Smith et al. [32], 의 연구결과에 의하면 전방 십자인대가 손상된 여자 운동선수(Lacrosse, Soccer, Basketball, Football, Field hockey, Gymnatstics) 19 명을 대상으로 착지오류점수시스템을 분석한 결과 5.49 
로 나타나 보통의 착지수준을 가지고 있다고 보고하였 으며 또한, Padua et al. [18] , 의 연구결과에 의하면 전방십자인 손상 예방을 위하여 측정한 전체 착지오류 점수시스템 평균 점수가 4.92점으로 좋은 착지수준을 가지고 있다고 보고하고 있다. Cho et al. [21] , 은 경 력 10년 이상 된 엘리트 국가대표 20대 여자 펜싱선수 집단의 경우 5.09점, 20대 남자 펜싱선수 집단의 경우 2.47점으로 나타나 남자 펜싱선수 집단이 여자 펜싱선 수 집단보다 우수한 착지 기술을 가지고 있는 것으로 보 고하였다. 이렇듯 여러 연구자들에게서 다양한 연구결 과를 보고하고 있으며, 이는 운동종목(발레, 축구, 라크 로스, 농구, 하키, 체조, 펜싱 등)의 차이가 결과에 영향 을 미치는 것으로 판단된다.

Padua et al. [15, 18], 이 제시한 $30 \mathrm{~cm}$ 높이의 박 스 위에서 자신의 신장의 $50 \%$ 거리 떨어진 지점에 양 발 착지 후 수직으로 점프하는 동작에서 근육량은 전방십자 인대 손상위험에 영향을 미친 것으로 나타났다. 이 연구 에서 새롭게 제시한 $45 \mathrm{~cm}$ 높이의 박스 위에서 자신의 신장의 $50 \%$ 거리 떨어진 지점과 $75 \%$ 거리 떨어진 지점 에 양 발 착지 후 수직으로 점프하는 동작에서 근육량이 체중의 몇 퍼센트를 차지하는지를 나타내는 근육률이 전 방십자인대 손상위험에 영향을 미친 것으로 나타났다.

\section{결론}

착지오류점수시스템 은 근육률이 낮은 저근육 집단 이 근육률이 높은 고근육 집단보다 착지자세의 오류로 인한 전방십자인대 손상 위험이 더 높게 나타났다. 결론 적으로 성인 여성의 근육률은 전방십자인대 손상과 밀 접한 관련이 있는 것으로 나타났다. 본 연구에서 다양한 방법으로 제시한 박스 높이 $(30 \mathrm{~cm}$ 와 $45 \mathrm{~cm}$ )와 거리(자 신의 신장의 $50 \%$ 와 $75 \%$ ) 과제 이외에도 더 다양한 방 법으로 체내 근육률과 전방십자인대 손상 위험과의 관 계를 밝히는 후속연구가 필요할 것으로 판단된다. 또한, 착지오류점수시스템에서 확인된 전방십자인대 손상 예 방 운동프로그램 구성에 체내 근육률을 향상시키는 운 동의 필요성을 인식하고 포함되어야 할 것을 제안한다.

\section{Acknowledgments}

이 논문은 저자의 연구활동과 관련된 연구비를 지원 받 은 것이 없음.

\section{Conflicts of Interest}

The authors declare no conflict of interest.

\section{References}

1. Hawkins RD, Hulse MA, Wilkinson C, Hodson A, Gibson $\mathrm{M}$. The association football medical research program: an audit of injuries in professional football. Br J Sports Med. 2001; 35:43-47.

2. Dufek JS, Bates BT. The evaluation and prediction of impact forces during landings. Med Sci Sports Exerc. 1990; 22:370-377.

3. Bell DR, Smith MD, Pennuto AP, Stiffler MR, Olson ME. Jump-landing mechanics after anterior cruciate ligament reconstruction: a landing error scoring system study. J Athl Train. 2014; 49(4):435-441.

4. Stiffler MR, Pennuto AP, Smith MD, Olson ME, Bell DR. Range of motion, postural alignment, and LESS score differences of those with and without excessive medial knee displacement. Clin J Sport Med. 2015; 25(1):61-66.

5. Kim KW, Lim BO. Effects of Female Ages on the Noncontact Anterior Cruciate Ligament Injury Risk Factors During the Single Legged Drop Landing. Korean J Sport Sci. 2011; 22(1):1693-1700.

6. Lim BO. The effects of knee brace on the knee extensor and valgus moment during the rebound in female high school basketball player. Korean J Phys Edu. 2007; 46:509-514.

7. Ford KR, Shapiro R, Myer GD, Van Den Bogert AJ, Hewett TE. Longitudinal sex differences during landing in knee abduction in young athletes. Med Sci Sports Exerc. 2010; 42:1923-1931.

8. Chappell JD, Yu B, Kirkendall DT, Garrett WE. A comparison of knee kinetics between male and female recreational athletic in stop-jump tasks. Am J Sports Med. 2002; 30:261-267.

9. Myklebust G, Maehlum S, Holm I, Bahr R. A prospective cohort study of anterior cruciate ligament injuries in elite Norwegian team handball. Scand J Med Sci Sports. 1998; 8:149-153. 
10. Decker MJ, Torry MR, Wyland DJ. Sterett WI, Richard Steadman J. Gender differences in lower extremity kinematics, kinetics and energy absorption during landing. Clin Biomech. 2003; 18:662-669.

11. Hewett TE, Lindenfeld TN, Riccobene JV, Noyes FR. The effects of neuromuscular training on the incidence of knee injury in female athletes. Am J Sports Med. 1999; 27:699-705.

12. Hewett TE, Myer GD, Ford KR. Anterior cruciate ligament injuries in female athletes: Part 1 , mechanisms and risk factors. Am J Sports Med. 2006; 34:299-311.

13. Ahmad CS, Clark AM, Heilmann N, Schoeb JS, Gardner TR, Levine WN. Effect of gender and maturity on quadriceps-to-hamstring strength ratio and anterior cruciate ligament laxity. Am J Sports Med. 2006; 34:370-374.

14. Renstrom P, Ljungqvist A, Arendt E, et al. Non-contact ACL injuries in female athletes: an International Olympic Committee current concepts statement. Br J Sports Med. 2008; 42:394-412.

15. Padua DA, DiStefano LJ, Beutler AI, de la Motte SJ, DiStefano MJ, Marshall SW. The Landing Error Scoring System as a Screening Tool for an Anterior Cruciate Ligament Injury-Prevention Program in Elite-Youth Soccer Athletes. J Athl Train. 2015; 50(6):589-595.

16. Quatman CE, Ford KR, Myer GD, Hewett TE. Maturation leads to gender differences in landing force and vertical jump performance: A longitudinal study. Am J Sports Med. 2006; 34:806-813.

17. Olsen OE, Myklebust G, Engebretsen L, Bahr R. Injury mechanisms for anterior cruciate ligament injuries in team handball: a systematic video analysis. Am J Sports Med. 2004; 32:1002-1012.

18. Padua DA, Marshall SW, Boling MC, Thigpen CA, Garrett WE, Jr Beutler AI. The Landing Error Scoring System (LESS) is a valid and reliable clinical assessment tool of jump-landing biomechanics: The JUMP-ACL study. Am J Sports Med. 2009; 37:1996-2002.

19. James J, Ambegaonkar JP, Caswell SV, Onate J, Cortes N. Analyses of Landing Mechanics in Division I Athletes Using the Landing Error Scoring System. Sports Health.
2016; 8(2):182-186.

20. Cho JH, Lim ST, Lim BO, Moon JW. Assessment of Risk Factors for Anterior Cruciate Ligament in Female Adolescents and Adults. Korean J Grow Dev. 2018a; 26(4):455-460.

21. Cho JH, Chung JW, Lee KH, Lim BO. Analysis of Landing Error Scoring System during Drop Vertical Jump on Anterior Cruciate Ligament Injury Risk Factors in Elite Fencers. Korean J Sports Med. 2018b; 36(3):107-117.

22. Kim HJ, Kim JD, Kim MY. Effects of female maturation on the lower extremity injury risk factors during the box drop landing. Korean J Phy Edu. 2010; 49(1):437-443.

23. Cho JH, Lim BO. Correlation Analysis of Landing Error Score and Lower Body stiffness for Evaluating Anterior Cruciate Ligament Risk Factors in Female Soccer Players. J Kines. 2017; 19(4):57-63.

24. Cho JH, An KO, Cho EO, Lim BO. Analysis of Landing Error Scoring System During Drop Vertical Jump on Anterior Cruciate Ligament Injury Risk Factors in Female Ballet Dancers and Female Soccer Players. Korean J Sports Med. 2015; 33(2):88-95.

25. Beese ME, Joy E, Switzler CL, Hicks-Little CA. Landing Error Scoring System Differences Between Single-Sport and Multi-Sport Female High School-Aged Athletes. J Athl Train. 2015; 50:806-811.

26. DiStefano LJ, Martinez JC, Crowley E, et al. Maturation and sex differences in neuromuscular characteristics of youth athletes. J Strength Cond Res. 2015; 29:24652473.

27. Hootman JM, Dick R, Agel J. Epidemiology of collegiate injuries for 15 sports: summary and recommendations for injury prevention initiatives. J Athl Train. 2007; 42:311-319.

28. Korean Society for the Study Obesity. Obesity medical guideline 2018. Korean Society for the Study Obesity, 2018, p 5-6.

29. American College of Sports Medicine. ACSM's guidelines for exercise testing and prescription. 8th ed, Lippincott Williams \& Wilkins, 2016, p 59-67.

30. Jackson AS, Pollock ML. Generalized equations for predicting body density of men. British Journal of 
Nutrition. 1979; 40:497-504.

31. Kinovea. VO.8.15; Kinovea open source project. http:// www.kinovea.org.
32. Smith HC, Johnson RJ, Shultz SJ, et al. A prospective evaluation of the Landing Error Scoring System (LESS) as a screening tool for anterior cruciate ligament injury risk. Am J Sports Med. 2012; 40:521-526. 